\title{
Simulation of Network Maneuvers at Power Substantions
}

\author{
${\text { Marwan Marwan,a,", Kurniawati Naim }{ }^{1} \text {, Devi Nurfitriani Qadarsih }}^{1}$ \\ ${ }^{1}$ Electrical Engineering Department, State Polytechnic of Ujung Pandang, Jl. Perintis Kemerdekaan Km.10 Tamalanrea \\ Makassar, 90245, Indonesia \\ a,* Email :marwan@poliupg.ac.id (Corresponding Author)
}

\begin{abstract}
The purpose of this study is to simulate network maneuvers due to disruption in the distribution system. This research was conducted in the Daya substation from January to March 2019, transformer 20 MVA. To achieve the research goal, network maneuvers were carried out in accordance with the standard operation procedure (SOP) of PT. PLN by simulating the conditions before and after the maneuver under Digsilent. Based on the results of the study, it shows that there is a change in the loading value of several back-up feeders to cover consumers demand for day and night time.
\end{abstract}

Keywords-Demand; Distribution; Maneuver; Feeders

\section{Introduction}

Along with the population growth, the need for electricity increases [1], [2]. This is because electrical energy has become a major need for every individual. Moreover, the development of technology becomes the cause of people's dependence on electrical energy. Modern society's lifestyle has also changed people's lifestyles to use more electricity than other energy.

In terms of meeting the increasing needs of electrical energy, PT. PLN as a national electricity provider is required to be able to provide continuous, quality and reliable services. Thus in anticipating the development of increasing burdens continuously, it is necessary to do some strategies in dealing with conditions like this.

The availability of sufficient electrical energy is not a guarantee of maximum consumer service. Outages are often unavoidable due to system disruption and/or maintenance. Therefore, a strategy is needed in serving a critical burden. One of them is the load maneuver carried out to minimize blackouts due to disruptions that occur.

Therefore, to maintain the reliability, quality and continuity of service to consumers, network maneuvering as one of the strategies carried out when there is a sudden disruption to the distribution or maintenance network carried out by pt. PLN. Simulation is conducted as a first step in anticipating when disruption or maintenance actually occurs. As a result, the management of PT. PLN can calculate in real terms the impact that arises from maneuvering actions carried out when the outage actually occurs.

According to [3], network maneuvering is an activity that is carried out to modify the network by opening or closing switching equipment so that it can avoid blackouts according to certain needs or regions only. According to [4], network maneuvers are carried out to avoid blackouts in order to reduce the extinguishment area in order to still achieve the maximum possible electric power distribution conditions. In carrying out the Standard Operation Procedure (SOP) of network maneuvering, the following are described some steps that must be done, such as:

1. Connects separate parts of the network according to their normal operating circumstances, (whether in voltage or not).

2. Separating the network into parts of the network that were originally connected according to its normal operating state, either under its normal operating state, and in a state of voltage or not.

In this study, the selection of Sanmaru refinery power substation and Golf Course was chosen because it serves several industry loads as the main load and critical load. Some industries still make PLN's electricity source as the main source in establishing and/or operating their factories.

Research on network maneuvers has been done before in several different places. The studies were 
conducted at Bawen 2 [5], Ampenan Area [6] and Batulicin [7]. From the conducted researches, it can be concluded that the purpose of the network maneuver can be categorized into:

1. Optimizing the distribution of electric power.

2. Minimize the area of power outages in the event of sudden disruption or planned /sudden disruption.

3. Avoiding power outages for consumers that are categorized as critical burdens.

Load maneuvering is not the only way that has been done by PT. PLN in maintaining the reliability of the system, several methods have been carried out and developed by electricity providers such as: SAIDI and SAIFI [8]-[10].

In addition, some researchers have previously also conducted several studies in evaluating the reliability of the system in several different places, such as: sequential simulation approach [11], [12], Fuzzy Bayesian learning [13] and practical swam optimization [14], [15].

\section{Research Methodology}

The method used in this study is network maneuvering based on the standard operation procedure (SOP) of PT. PLN. In conducting the analysis, simulations were conducted on the feeder before and after the maneuver using the DigSilent program. The data analysis was conducted on Sanmaru feeders and Golf Courses at the 20 MVA \#1 Transformer in GI Daya Makassar.

In maneuvering the network some things are taken into consideration at the time of the crossing as described below:

1. The sequence of phases between feeders must be the same,

2. The voltage between feeders must be the same, in this case the range $( \pm 5 \%)$

3. Set the equipment such as recloser and PMT,

4. Feeders that will be burdened must be able to shoulder the total load at peak load hours,

5. If the transformer is different, then the transformer that will receive the load diversion must be able to carry the load at peak load hours.

As well as some additional requirements, as follows:

1. Pay attention to standard operating procedure (SOP) load maneuvers.
2. See the golf course and Sanmaru turtle track with the feeder path that will receive the diversion of the burden of the two feeders to ensure a meeting to connect the two. Example: LBS in an open state.

3. The frequency of the main feeder and the feeder who will receive the transfer of the main feeder's load, must be the same.

The first step that has been done is to calculate the burden on golf course and Sanmaru feeders and reserve feeders as feeders who will receive load diversion. This is done to ensure that the burden of reserve feeders and main feeders does not exceed the maximum limit of reserve feeders by $80 \%$ of the flow of prisoners.

To facilitate the evaluation, the following flowchart describes the steps that have been done in achieving research goals.

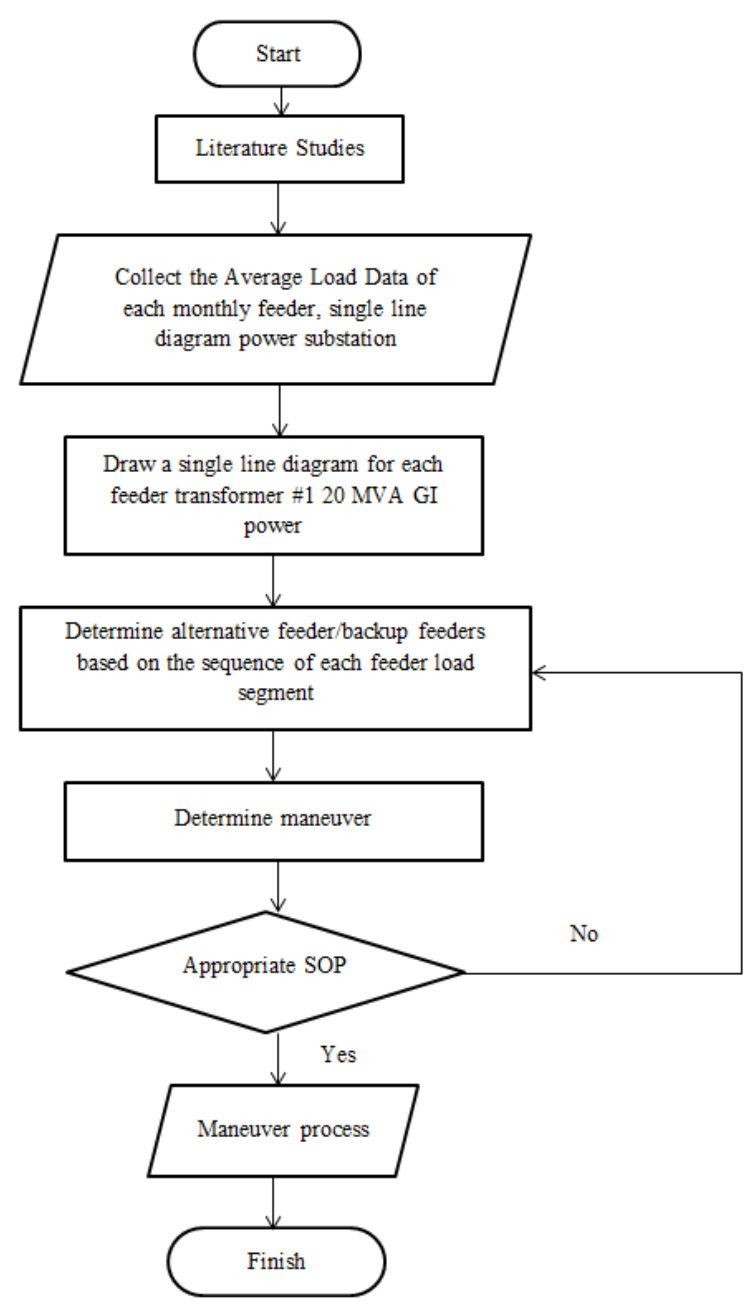

Figure 1. Research Flowchart 


\section{Results and Discussions}

To maneuver the golf course's network and Sanmaru, it is necessary to explain in advance the Single Line Diagram of the two refiners as illustrated through the following Figure 2.

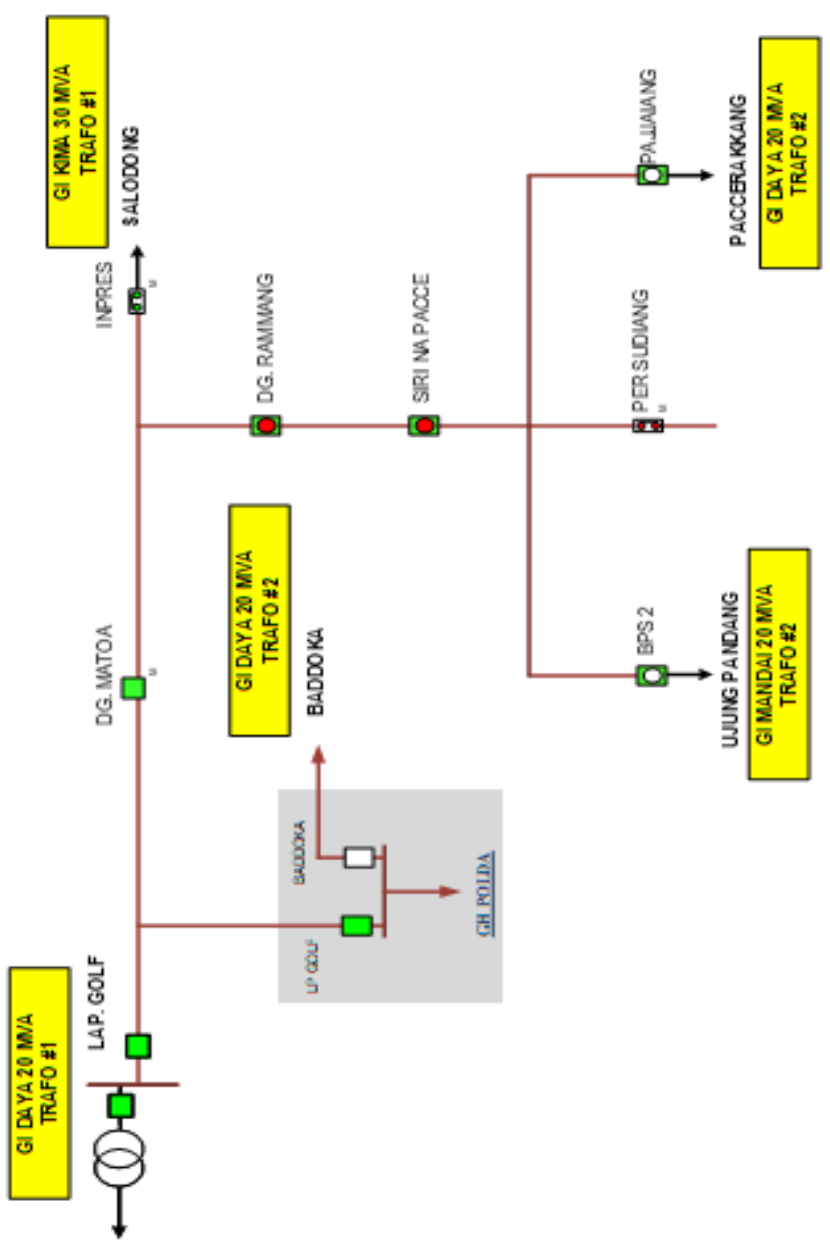

Figure 2. Single Line Diagram of Golf Course Feeder

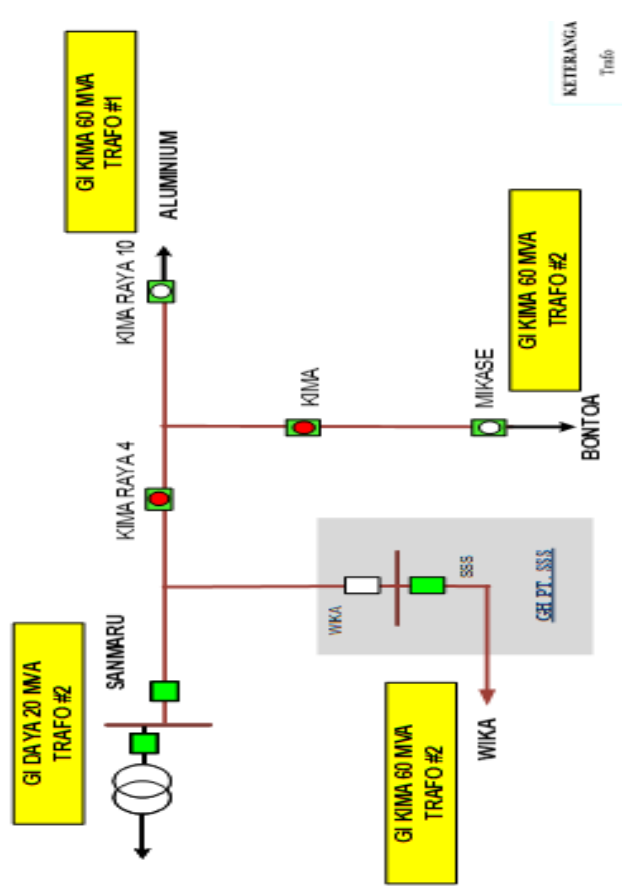

Figure 3. Single Line Diagram of Sanmaru Feeder

1. Normal Conditions

The following table shows data on load tamping power feeders (Ampere) for Golf Course and Sanmaru feeders:

Table 1. Tamping the weight of golf course feeder and Sanmaru 2015-2016

\begin{tabular}{|c|c|c|}
\hline Time & Golf Course & Sanmaru \\
\hline Day & $115 \mathrm{~A}$ & $202 \mathrm{~A}$ \\
\hline Night & $134 \mathrm{~A}$ & $179 \mathrm{~A}$ \\
\hline
\end{tabular}

2. Conditions due to disruption.

As it is known that the alternative golf course feeders are Baddoka feeder Daya substation, Paccerakkang feeder Daya substation, Ujung Pandang feeder Mandai substation, and Salodong feeder kima substation. The following table explains the accumulated load for backup feeders. 
Table 2. Accumulated load of golf course feeders and their reserves

\begin{tabular}{|c|c|c|c|c|}
\hline Time & $\begin{array}{c}\text { Baddoka } \\
(\mathrm{A})\end{array}$ & $\begin{array}{c}\text { Paccerakkang } \\
(\mathrm{A})\end{array}$ & $\begin{array}{c}\text { Ujung } \\
\text { Pandang (A) }\end{array}$ & $\begin{array}{c}\text { Salodong } \\
(\mathrm{A})\end{array}$ \\
\hline Day & 98 & 148 & 142 & 111 \\
\hline Night & 101 & 187 & 177 & 115 \\
\hline
\end{tabular}

Because Baddoka feeder and golf course enthusiasts are in the same substation, the value of frequency, voltage, and transformer power capabilities have been fulfilled. As for the phase sequence, PLN will first confirm whether the phase sequence of the two feeders is the same or not. If not, then the officer first changes the phase order. This is done based on the SOP on network maneuvering.

As soon as the above conditions are met, the officer maneuvers the network by transferring the burden of the golf course feeder network to Baddoka feeder with the following SOP:

1. Pay attention to the standard operating procedure (SOP) that has been set.

2. First, release the PMT golf course.

3. Then transfer the load supply to Out_Baddoka - GH Polda, by informing UP3 North Makassar to change its position from open to close ( $\square \rightarrow \square$ ).

4. The burden of golf course feeders has been sidetracked connected with Baddoka feeders network. Here is a table of changes in the weight value of Golf Course Feeder after being maneuvered.

5. Always pay attention to the increase in the burden of reserve feeders.

The following table 3 shows the accumulated load after the maneuver.

Table 3. Accumulated load after maneuver (Golf course)

\begin{tabular}{|c|c|c|c|c|}
\hline Time & $\begin{array}{c}\text { Baddoka } \\
\text { (A) }\end{array}$ & $\begin{array}{c}\text { Paccerakkang } \\
\text { (A) }\end{array}$ & $\begin{array}{c}\text { Ujung } \\
\text { Pandang (A) }\end{array}$ & $\begin{array}{c}\text { Salodong } \\
(\mathrm{A})\end{array}$ \\
\hline Day & 213 & 263 & 257 & 226 \\
\hline Night & 215 & 321 & 311 & 249 \\
\hline
\end{tabular}

Based on Figure 3 above, the Sanmaru feeder has several alternatives as backup feeders, such as: Wika feeder at Kima Substation, Bontoa feeder at Kima substation and aluminum feeder at Kima substation.
Table 4. Sanmaru Feeder Load Accumulation and Reserves.

\begin{tabular}{|c|c|c|c|}
\hline Time & $\begin{array}{c}\text { Wika } \\
(\mathrm{A})\end{array}$ & $\begin{array}{c}\text { Bontoa } \\
(\mathrm{A})\end{array}$ & $\begin{array}{c}\text { Aluminium } \\
(\mathrm{A})\end{array}$ \\
\hline Day & 131 & 177 & 218 \\
\hline Night & 98 & 111 & 144 \\
\hline
\end{tabular}

Since Sanmaru and the three backup feeders are located at different substations, it is necessary to pay attention to wether the frequency, voltage, and power capability values of the transformer have not been fulfilled or have been fulfilled. As for the phase sequence, PLN will first confirm wether the phase sequence of the feeders is the same of not. If not, the officer will first change the phase order.

Immediately after the conditions are met, maneuvers are carried out with the following steps:

1. Observing the established Standard Operating Procedure (SOP).

2. First, remove the Sanmaru feeder PMT.

3. Then each enter Inc_Wika-GH PT.SSS to transfer the load to the Wika feeder; Sect_Mikase for load shifting to Bontoa feeder; Sect_Kima Raya 10 for load transfer to Aluminum feeder by dispatcher via remote SCADA. So the position changes from open to close ( $\square \rightarrow \square$ ).

4. The load of the Sanmaru feeder has been transferred to the network of the Wika feeder, the Bontoa feeder, and the Aluminum feeder.

5. Always pay attention to the increase in the burden of reserve feeders.

The following table 5 shows the accumulated load after the maneuver.

Table 5. Load Accumulation after Maneuver (Sanmaru)

\begin{tabular}{|c|c|c|c|}
\hline Day & $\begin{array}{c}\text { Wika } \\
(\mathrm{A})\end{array}$ & $\begin{array}{c}\text { Bontoa } \\
(\mathrm{A})\end{array}$ & $\begin{array}{c}\text { Aluminium } \\
(\mathrm{A})\end{array}$ \\
\hline Day & 156 & 263 & 291 \\
\hline Night & 123 & 197 & 217 \\
\hline
\end{tabular}

The table above shows that the aluminum feeder has the largest load after the maneuver, by about 291 A (day) and 217 A (night). Followed by the Bontoa and Wika feeders with each load of $263 \mathrm{~A}$ and $156 \mathrm{~A}$ during the day and $197 \mathrm{~A}$ and $123 \mathrm{~A}$ at night. 


\section{Conclusion}

Based on the evaluation results, it can be concluded that there was a change in the value of the load after maneuvering the network against several back-up feeders during the day and night. The biggest load change is the Paccerakang feeder of $263 \mathrm{~A}$ (day) and 321 A (night) when there is a network maneuver on the golf course feeder. Likewise, if the network maneuver is carried out on the Sanmaru feeder, the largest load on the Aluminum reserve feeder is $291 \mathrm{~A}$ (day) and $217 \mathrm{~A}$ (night).

\section{Acknowledgement}

Authors would like to thank the State Polytechnic of Ujung Pandang and Ministry of Education, Culture, Research and Technology for supporting the research.

\section{References}

[1] He, Y. "Agricultural population urbanization, long-run economic growth, and metropolitan electricity consumption: An empirical dynamic general equilibrium model ", Energy Strategy Reviews Vol 30, pp.1-9. 2020.

[2] Shetty, V.J., et al.,"Distribution system Network Reconfiguration for Voltage profile improvement and loss reduction Using BPSO",2nd International Conference on Power and Embedded Drive Control (ICPEDC), Chennai India, 2019.

[3] Apsari, A.P., "Simulasi manuver jaringan distribusi tegangan menengah $20 \mathrm{kV}$ dengan LBS join untuk pelimpahan beban menggunakan VT Scada 11.2 berbasis Arduino Mega 2560", $(20 \mathrm{kV}$ medium voltage distribution network maneuver simulation with LBS join for load transfer using VT Scada 11.2 based on Arduino Mega 2560), Institution Teknik elektro, Universitas Dipanegoro, 2018.

[4] Wiyono, T., "Optimalisasi Titik Manuver Penyulang Anggur GI Boombaru Dengan Analisis Rugi-Rugi Daya", (Optimization of the Maneuver Point of the Boombaru GI Wineryer with Power Loss Analysis), Institution Fakultas Teknik, Universitas Tridinanti Palembang, Palembang, 2020.

[5] Adikinasih, D.R., "Analisa drop tegangan dan manuver jaringannya pada penyulang Bawen 2 dengan etap power station 12.6", (Analysis of voltage drop and network maneuvering on Bawen 2 feeder with 12.6 . power station stage), Institution Teknik elektro, Universitas Muahmmadiyah Surakarta, 2018.

[6] Hidayah, N., S. Supriyatna, and A.B. Muljono. "Analisis manuver jaringan terhadap keandalan kontinuitas penyaluran tenaga listrik penyulang diarea Ampenan", (Analysis of network maneuvers on the reliability of the continuity of the distribution of electricity to the feeder in the Ampenan area), Dielektrika, Vol 3, pp.109-115. 2014.

[7] Ode, A.K. and M. Faridha. "Pengaruh Manuver Jaringan Distribusi $20 \mathrm{Kv}$ Terhadap Indeks Keandalan Penyulang BT07 Batulicin", (Effect of $20 \mathrm{Kv}$ Distribution Network Maneuver on Feeder Reliability Index BT07 Batulicin), Jurnal Electric, Electronic, Instrumentation, Control, Telecommunication, Vol 3, pp.29-38. 2020.

[8] Hajar, I. and M.H. Pratama. "Analisa Nilai SAIDI SAIFI sebagai indeks keandalan penyediaan tenaga listrik pada penyulang Cahaya PT. PLN (Persero) area Ciputat", (SAIDI SAIFI Value Analysis as an index of the reliability of electricity supply at PT. PLN (Persero) Ciputat area), Energi dan Kelistrikan, Vol 10, pp.70-77.2018.

[9] Burian, R., M. Gontijo, and H. Alvarez."Robustness and Reliability in Smart Grid Solutions",7th International Conference on Smart Energy Grid Engineering (SEGE), Oshawa, ON, Canada, 2019.

[10] Habib, M.Z., et al.,"Impact of the fault location methods on SAIDI of a resonant-earthed distribution system",International Conference on Power Systems Technology (POWERCON), Bangalore, India, 2020.

[11] Peng, L., et al. "Analytical model for fast reliability evaluation of composite generation and transmission system based on sequential Monte Carlo simulation", International Journal of Electrical Power \& Energy Systems, Vol 109, pp.548-557. 2019.

[12] Shu, Z., P. Jirutitijaroen, and B. Bordeerath."Reliability evaluation of composite power systems using sequential simulation with Latin Hypercube Sampling",Power Systems Computation Conference, Wroclaw, Poland, 2014.

[13] Yi, Z., Z. Xin-gang, and Z. Yu-zhuo. "Bargaining strategies in bilateral electricity trading based on fuzzy Bayesian learning", International Journal of Electrical Power \& Energy Systems, Vol 129. 2021.

[14] Huang, Q., et al.,"Reactive Power optimization for Distribution Network Based on Improved Bacterial Chemotaxis Particle Swarm optimization",12th International Symposium on Computational Intelligence and Design (ISCID), Hangzhou, China, 2019.

[15] Abugri, J.B. and M. Karam."Particle Swarm Optimization for the Minimization of Power Losses in Distribution Networks",12th International Conference on Information Technology - New Generations, Las Vegas, NV, USA, 2015. 